\title{
Studies on Carob (Ceratonia siliqua L.) Propagation
}

\author{
${ }^{1}$ Eid Mohamed Zaen El Deen, ${ }^{2}$ Omima Mostafa El-Sayed, ${ }^{3}$ Abd El-Rahman \\ Ibrahim El-Sayed, ${ }^{4}$ Ghada Abd El-Moneim Hegazi* \\ ${ }^{1,2,3,4}$ Ecology and Dry Land Agriculture Division, Desert Research Center, 11753 El-Matarya, 1 Mathaf El- \\ Matarya St., Cairo, Egypt
}

\begin{abstract}
Carob (Ceratonia siliqua L.) is an environmentally and economically important tree and is among the most difficult to propagate fruit species. In this study, efforts were made to propagate the plant by using three different methods; seeds germination, cuttings and micropropagation. Seeds and cuttings were scarified and disinfected under aseptic conditions to improve the germination percentage and the percentage of success of cuttings in April and September through two successive seasons (2011 and 2012). Results showed that the highest values of seed germination percentage, the fastest germination, the greatest plant length, number of leaves/plant, root length and dry weight were obtained by soaking seeds in $60 \% \mathrm{H}_{2} \mathrm{SO}_{4}$ in April and September through the two seasons, but there was no significant difference between the first and the second date in both studied seasons for most of the studied parameters. April was found the best time for propagation of Carob by cuttings, for all treatments. Besides, carob cuttings treated with indole-3-butyric acid (IBA) at $8000 \mathrm{mg} / \mathrm{l}+\beta$ naphthalene acetic acid (NAA) at $200 \mathrm{mg} / \mathrm{l}$ gave the highest values of parameters (shoot length, no. of lateral shoot, no. of leaves/plant, root length, no. of roots/plant and root dry weight) followed by IBA at $6000 \mathrm{mg} / \mathrm{l}+$ $N A A$ at $200 \mathrm{mg} / \mathrm{l}$, in both seasons. While, all cuttings failed to root for all treatments in September, except when they were treated with IBA at $6000 \mathrm{mg} / \mathrm{l}+N A A$ at $200 \mathrm{mg} / \mathrm{l}$ and IBA at $8000 \mathrm{mg} / \mathrm{l}+N A A$ at $200 \mathrm{mg} / \mathrm{l}$, in the two studied seasons. Micropropagation of carob was developed by using shoot tips and stem node segments, of ex vitro grown seedlings, as explants. Hundred \% of growth induction was obtained, for both explants, with the highest number of shoots on Murashige and Skoog (MS) medium containing $0.4 \mathrm{mg} / \mathrm{l} \mathrm{NAA}+2 \mathrm{mg} / \mathrm{l} \mathrm{6}$ benzylaminopurine (BAP). Shoots were best multiplied on MS medium containing BAP (1.0 mg/l), while the media containing N6-(2-isopentenyl) adenine (2iP) gave the highest lengths of shoots (2iP at $1.0 \mathrm{mg} / \mathrm{l})$. For further elongation and multiplication of shoots, the combination of both BAP and $2 i P$ gave promising results at concentrations of $0.5 \mathrm{mg} / \mathrm{l} B A P+0.5 \mathrm{mg} / \mathrm{l} 2 i P$ or $1.0 \mathrm{mg} / \mathrm{l} B A P+0.5 \mathrm{mg} / \mathrm{l} 2 i P$. Attempts to achieve rooting were unsuccessful, since only shoot development was observed.
\end{abstract}

Key Words: Carob, propagation, germination, cuttings, micropropagation.

Abbreviations: BAP, 6-benzylaminopurine; $\mathbf{G A}_{3}$, gibberellic acid; IBA, indole-3-butyric acid; 2iP, N6-(2isopentenyl) adenine; MS, Murashige and Skoog; NAA, $\beta$-naphthalene acetic acid; TDZ, Thidiazuron; PGRs, plant growth regulators

\section{Introduction}

Carob tree (Ceratonia siliqua L.) belongs to family Fabaceae. It is a long-lived evergreen and thermophilous fruit and forms an important part of Mediterranean vegetation (Battle and Tous, 1997). Carob is native to the eastern Mediterranean, probably the Middle East, where it has been in cultivation for at least 4000 years. It grows well in the Mediterranean basin, and some parts of Western Asia and the Middle East. The tree is well adapted to mild and dry areas with poor soils. It is often interplant with olives, grapes, almonds, and barley in low intensive farming system. It grows well in warm temperate and subtropical areas. It tolerates adverse conditions, drought, and alkali soils and is extremely tolerant to heat and dry atmosphere. They are used naturally against soil erosion and land reclamation in most Mediterranean areas (Janick and Paull, 2008).

Carob is well known in the Mediterranean countries for its ornamental, nutritional and medicinal value (Battle and Tous, 1997). Carob pods were also used in ancient Egypt, where the pulp of the pods was mixed in porridge, with a little honey, and wax as a treatment for diarrhea and some other diseases. The trees are also useful as ornamentals and for landscaping, windbreaks and a forestation. Cattle can browse on leaves and the wood is suitable for fuel (Shereen et al., 2011). Annual world production of Carob pods mainly from Mediterranean countries including Spain, Italy and Portugal reaches 180.000 tons. As an origin country of Carob, Turkey produces around 14.000 tons Carob annually (Anonymous, 2009).

Carob trees may be male, female and hermaphrodite or play gummous inflorescences, showing high plasticity in inflorescences and flowering characteristics. Female cultivars are the most important trees commercial groves of Mediterranean countries (Laubscher and Ndakidemi, 2008). 
Carob may be propagated by seeds, budding, grafting or cutting (Romano et al., 2002), and has been described by Lee et al. (1977) and Hartman and Kester (1983) as one of the most difficult species to root. Carob seeds are difficult to germinate. The seed coat is extremely hard and not ready to absorb water (Gubbuk et al., 2011). Alorda et al. (1987), Cabrita et al. (1988), Martins-Louçao et al. (1996) and Piotto and Di Noi (2003) showed that the best pre-sowing treatments for enhancing Carob seeds germination were chemical scarification with acids, treatment with warm water and scarification with the appropriate machines (mechanical scarification). Esma et al. (2009) study evaluated the effect of different $\mathrm{H}_{2} \mathrm{SO}_{4}$ concentrations on seed germination. Seeds, obtained from wild types of Carob were used as the experimental material. In this respect, scarified Carob seeds were treated with different $\mathrm{H}_{2} \mathrm{SO}_{4}$ concentrations (control, 10, 20, 40, 60, 80 and $98 \%$ ) for 30 minutes in petri dishes at $26^{\circ} \mathrm{C}$ and placed in the plant growth chamber. The results of this study indicated that the lowest germination rate was $22.92 \%$ in the control treatment followed by $23.61 \%$ by soaking the seeds in $60 \% \mathrm{H}_{2} \mathrm{SO}_{4}$. The highest germination rate (93.06\%) was obtained with the treatment of $98 \% \mathrm{H}_{2} \mathrm{SO}_{4}$ for 30 minutes.

The art of propagation by cuttings is a very old technique popular in the field of horticulture. However, there are many species, which are difficult to root. In recent years, many such difficult to root species are made to root easily by use of root inducing chemicals and modifying the surrounding environment. Such attempts were successful to get higher rooting percentage and early rooting. The rooting generally affected by internal and external factors; i.e. type, date of taking and growth regulators application (Hartman et al., 2002, Manan et al., 2002; Gerakakis and Ozkaya, 2005; Laubscher and Ndakidemi, 2008; Mohy, 2009 and Sayed et al., 2010). Plastic tunnels with water mist gave the best rooting and vegetative growth followed by the cutting under plastic tunnels without mist in Hamelia patens (Elgimabi, 2009).

The use of micropropagation technique can be the solution to solve propagation problems in Carob and to faster its propagation (Gubbuk et al., 2011). It is also considered a technique for the preservation of plant genetic material, the development of plant breeding programs and the fast production of large quantities of propagation material (George, 1993). Efforts were made previously to micropropagate Carob tree from various explants; for example from seeds (Sebastian and McComb, 1986), explants from suckers of female trees (ElShafey et al., 1998), explants of mature trees of Galhosa and Mulata cultivars (Romano et al., 2002) or explants from in vitro germinated seedlings (Hakim et al., 2010 and Radi et al., 2013). However, little data are reported about micropropagation of carob in Egypt. Romano et al. (2002) reported that the composition of medium changed with the cultivar studied, which required an optimization in the composition of the culture medium used for the micropropagation of Carob coming from different geographical areas.

Therefore, the aim of this study was to optimize easy and reliable methods for rapid propagation of the Egyptian Carob (Ceratonia siliqua L.) by seeds, cuttings and by micropropagation. Also, to study the effect of date of Carob propagation by seeds or cuttings and some soaking or dipping treatments to overcome the difficulties of its propagation. This study reports, also, a trial for micropropagating Carob from seedling's explants, in order to fulfill the increasing demand for propagating this tree in Egypt.

\section{Materials and Methods}

This investigation was conducted through two seasons of 2011 and 2012 on Carob. The mature Carob seeds and cuttings were collected from a female tree grown at the Experimental Orchard Station of Horticulture Research Institute at Giza, Egypt. Seeds and cuttings were scarified and disinfected under aseptic conditions with some treatments to improve the germination percentage and the percentage of success of cuttings.

This investigation included three main experiments:

\section{Seeds Germination}

In a split plot design, the effect of two different dates of culture ( $1^{\text {st }}$ of April and $1^{\text {st }}$ of September), as a first factor, and some soaking and dipping treatments, as a second factor, on Carob seeds germination, were studied. The following treatments were applied to the seeds:

1- Control (untreated seeds).

2- Soaking in the water at $30^{\circ} \mathrm{C}$ for $72 \mathrm{~h}$.

3- Soaking in hot water for $10 \mathrm{~min}$, then in tap water at room temperature for $48 \mathrm{~h}$.

4- Dipping in $60 \% \mathrm{H}_{2} \mathrm{SO}_{4}$ for $30 \mathrm{~min}$. The seeds were then washed in running water for $1 \mathrm{~h}$ to remove any traces of acid, before being tested for germination.

5- Dipping in $\mathrm{GA}_{3}$ solution $(25 \mathrm{mg} / \mathrm{l})$ for $24 \mathrm{~h}$.

6- Dipping in $80 \%$ acetone.

All seeds were tested for germination by using four replicates (each contained 20 seeds). 


\section{Measurements}

The germination percentage $(\%)$, germination time (day), plant length $(\mathrm{cm})$, number of leaves/plant and root length $(\mathrm{cm})$ were recorded and roots after drying at $80^{\circ} \mathrm{C}$ were weighed.

\section{Vegetative propagation by cuttings}

In a split plot design, the effect of two different dates of culture ( $1^{\text {st }}$ of April and $1^{\text {st }}$ of September), as a first factor, and some growth regulators, as a second factor, on vegetative propagation by cuttings were studied. The following treatments were applied to the cuttings:

1- Control (dipping in water only).

2- Dipping in IBA at $6000 \mathrm{mg} / \mathrm{l}$.

3- Dipping in IBA at $8000 \mathrm{mg} / \mathrm{l}$.

4- Dipping in IBA at $6000 \mathrm{mg} / \mathrm{l}+\mathrm{NAA}$ at $100 \mathrm{mg} / \mathrm{l}$.

5- Dipping in IBA at $8000 \mathrm{mg} / \mathrm{l}+\mathrm{NAA}$ at $100 \mathrm{mg} / \mathrm{l}$.

6- Dipping in radecant contains $80 \%$ NAA.

After dipping in the previous treatments, cuttings were then cultivated in pots under a tunnel. Four replicates were prepared per treatment (ten stem cuttings for each replicate).

\section{Measurements}

Shoot length $(\mathrm{cm})$, number of lateral shoots, number of leaves/plant, root length $(\mathrm{cm})$ and number of roots/plant were recorded after 3 months of planting and roots after drying at $80^{\circ} \mathrm{C}$ were weighed.

\section{Micropropagation \\ Plant material and sterilization}

Shoot tips and stem node segments of Carob were collected from two months old seedlings grown in the greenhouse (from the first experiment). The explants were washed under running tap water followed by a detergent for $5 \mathrm{~min}$. Explants were immersed in an antioxidant solution containing $200 \mathrm{mg} / \mathrm{l}$ of both citric and ascorbic acid and kept in a refrigerator for $1 \mathrm{~h}$, to overcome the phenolic exudates. Surface sterilization was done by dipping both shoot tips and stem node segments for $20 \mathrm{~min}$ in 20 and $30 \%$ (v/v) commercial bleach solution (Clorox) (containing 3\% sodium hypochlorite), respectively. Finally explants were rinsed thoroughly with six changes of sterile distilled water. Explants were cultured vertically on sterile nutrient medium.

\section{Culture medium and conditions}

Explants were cultured on Murashige and Skoog (MS) basal medium (Duchefa, Haarlem, the Netherlands) (Murashige and Skoog, 1962) supplemented with 3\% (w/v) sucrose and gelled with $2.5 \mathrm{~g} / \mathrm{l}$ phytagel (Duchefa, Haarlem, the Netherlands). Different plant growth regulators (PGRs) - cytokinins (BAP, 2iP and TDZ) and auxins (NAA and IBA) (Sigma Cell Culture, min. 90\%, St. Louis, USA), at different concentrations $(\mathrm{mg} / \mathrm{l})$ - either individually or in combination, were added to the medium to optimize hormonal requirements for bud sprouting, multiple shoot induction and rooting, in addition to the control medium without PGRs. The $\mathrm{pH}$ of the medium was adjusted to 5.7-5.8 before autoclaving at a pressure of $1.06 \mathrm{Kg} \mathrm{cm}^{-2}$ and $121^{\circ} \mathrm{C}$ for $15 \mathrm{~min}$. All cultures were incubated in a culture room at $25 \pm 2^{\circ} \mathrm{C}$ with a $16-\mathrm{h}$ photoperiod under cool white fluorescent tubes $(\mathrm{F} 140 \mathrm{t} 9 \mathrm{~d} / 38$, Toshiba). At least 10 cultures were raised for each treatment and data were scored after 8 weeks of culture.

\section{Culture establishment, multiplication, elongation and rooting}

Various concentrations of BAP, $2 \mathrm{iP}$ or TDZ $(0.5,1.0$ and $2.0 \mathrm{mg} / \mathrm{l})$, in addition to $0.25 \mathrm{mg} / \mathrm{TDZ}$, in combination with NAA $(0.4 \mathrm{mg} / \mathrm{l})$ were added to the MS medium for the establishment and bud break. For multiplication of shoots, MS medium was supplemented with BAP or $2 \mathrm{iP}(0.5,1.0,2.0$ and $3.0 \mathrm{mg} / \mathrm{l})$, or in combination to enhance both multiplication and elongation.

The percentage of explants initiating growth, the mean number of shoots/explant and mean shoot length $(\mathrm{cm})$ were measured after 8 weeks of culture. The micropropagation cycle consisted of the regular subculture of produced shoots onto fresh medium.

Shoots regenerated from the multiplication stage were excised and transferred to MS medium supplemented with different concentrations of IBA $(0.5,1.0,2.0$ and $4.0 \mathrm{mg} / \mathrm{l})$, either individually or in combination with NAA at a concentration of $0.5 \mathrm{mg} / \mathrm{l}$, for in vitro root induction.

\section{Statistical analysis of data}

Analysis of variance (ANOVA) and Duncan's multiple range test (Duncan, 1955), as modified by Snedecor and Cochran (1998), were performed to analyze the obtained data. The differences among means of 
the recorded parameters for all treatments were tested for significance at 5\% level. Means followed by the same letter are not significantly different at $\mathrm{P} \leq 0.05$.

\section{Results and Discussion}

\section{Seeds germination}

The Carob seeds like those of the majority of legumes have germination difficulty. This is mainly due to an inhibition of seeds coat, because it is extremely hard and not ready to absorb water and consequently affects the germination. Seed germination percentage was significantly affected by all pre-sowing treatments in April as a first date and September as a second date in both studied seasons, 2011 and 2012 (Figures 1 and 2). The highest values of seed germination percentage were obtained with soaking seeds in $60 \% \mathrm{H}_{2} \mathrm{SO}_{4}$ in $\mathrm{April}_{\text {and }}$ September in both studied seasons, their values was recorded as 91.22 and $91.63 \%$, respectively, followed by the seeds that were treated with $25 \mathrm{mg} / 1 \mathrm{GA}_{3}(78.50$ and $78.55 \%)$ and hot water treatment (76.03 and 77.21\%), as compared with the control (25.69 and $25.43 \%$ ), in the first and second seasons, respectively.

On the other hand, the relationship between time of germination on Carob seeds and soaking treatments was shown in Figures 3 and 4. Seed germination time was significantly affected by all pre-sowing treatments (cold water, hot water, $60 \% \mathrm{H}_{2} \mathrm{SO}_{4}, 25 \mathrm{mg} / \mathrm{l} \mathrm{GA} 3$ and acetone) in the first (April) and second (September) dates of germination, in both studied seasons. In this respect, the fastest germination was recorded with $60 \% \mathrm{H}_{2} \mathrm{SO}_{4}$ (germination occurred after 7.24 and 7.20 days), followed by $25 \mathrm{mg} / 1 \mathrm{GA}_{3}$ (germination occurred after 8.07 and 7.92 days) and then the hot water (germination occurred after 8.50 and 8.77 days) in the first and second seasons, respectively. All these treatments were markedly higher than the control and other treatments. The longest germination time was 11 days for the control treatment (without any additives) in both studied seasons.

Results in Table 1 showed that all treatments were significantly different in plant length, number of leaves/plant, root length and root dry weight from the control, in both studied seasons. Besides, it is clear that there was no significant difference between first and second dates of germination (April and September) with respect to all studied parameters except for the number of leaves/plant in 2012 and the plant length in both seasons (2011 and 2012). Moreover, the interaction between soaking treatments and culture date showed significant differences in plant length, number of leaves/plant, root length and root dry weight, as compared with the control, in both the first and second seasons.

The greatest number of leaves/plant and plant length were found with $60 \% \mathrm{H}_{2} \mathrm{SO}_{4}$ treatment in both 2011 and 2012 seasons $\left(8.12,8.50\right.$ and $18.00,20.50 \mathrm{~cm}$, respectively), followed by $25 \mathrm{mg} / \mathrm{l} \mathrm{GA}_{3}(4.87,4.75$ and $16.25 \mathrm{~cm}$, respectively). However, the maximum root dry weight and length, in the two seasons, were obtained with the same treatments $\left(7.29,7.18\right.$ and $3.79,3.77 \mathrm{~cm}$, respectively), followed by $25 \mathrm{mg} / \mathrm{G} \mathrm{GA}_{3}(6.33,6.31$ and $3.29,3.38 \mathrm{~cm}$, respectively), as compared with the control and other treatments of the seeds (Table 1).

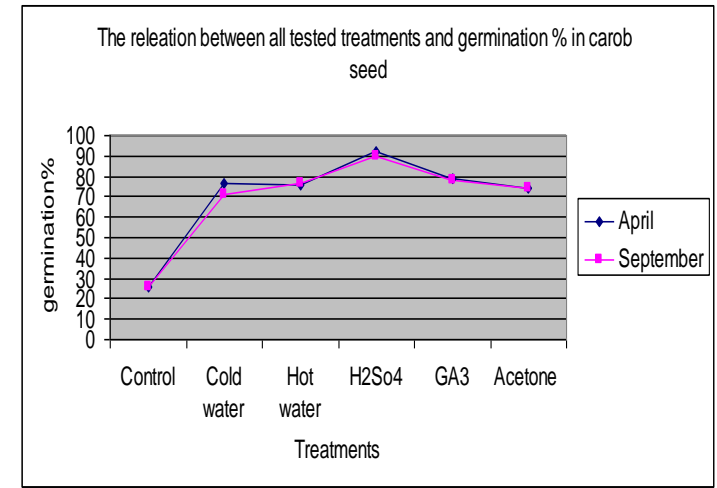

Figure 1. The effect of different pre-sowing treatments on the germination percentage of Carob seeds in 2011 seasons.

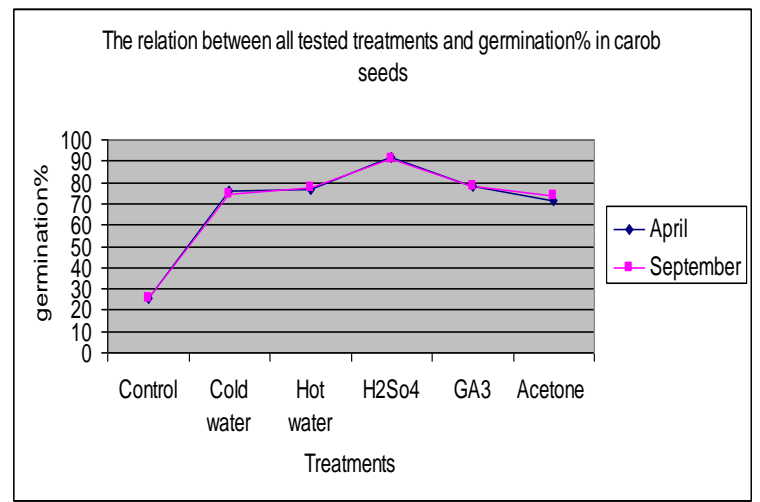

Figure 2. The effect of different pre-sowing treatments on the germination percentage of Carob seeds in 2012 seasons. 


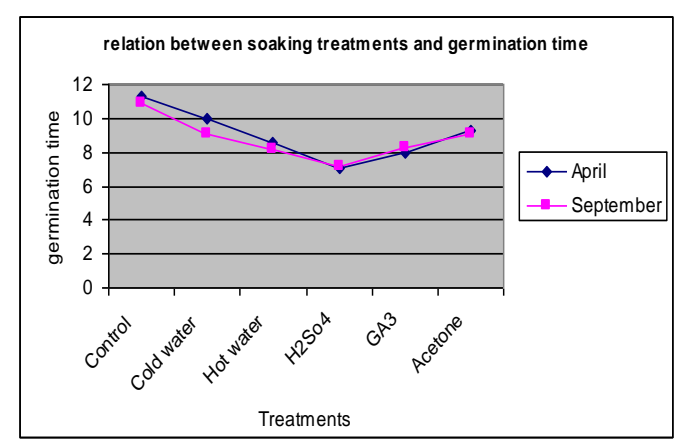

Figure 3. The effect of different pre-sowing treatments on the germination time of Carob seeds in 2011 seasons.

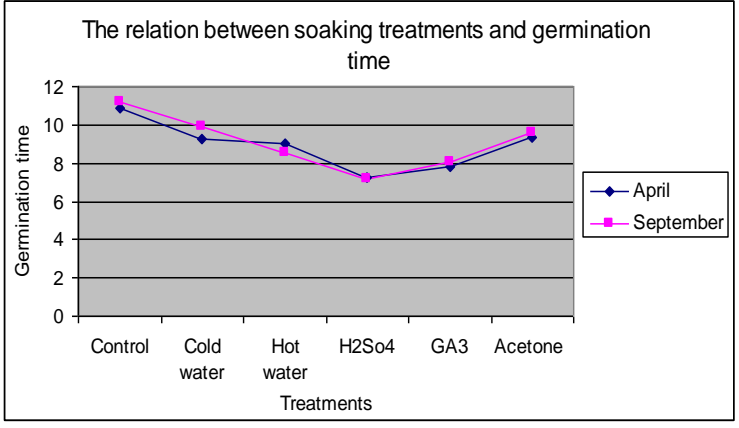

Figure 4. The effect of different pre-sowing treatments on the germination time of Carob seeds in 2012 seasons.

Table 1. Effect of some pre-sowing treatments and time of propagation by seeds on number of leaves/plant, plant length, root length and root dry weight of carob, during 2011 and 2012 seasons.

\begin{tabular}{|c|c|c|c|c|c|c|c|c|c|c|c|c|}
\hline \multirow{2}{*}{ Seasons } & \multicolumn{3}{|c|}{2011} & \multicolumn{3}{|c|}{2012} & \multicolumn{3}{|c|}{2011} & \multicolumn{3}{|c|}{2012} \\
\hline & April & Sep. & Mean & April & Sep. & Mean & April & Sep & Mean & April & Sep. & Mean \\
\hline & \multicolumn{6}{|c|}{ No. of leaves/plant } & \multicolumn{6}{|c|}{ Plant length $(\mathrm{cm})$} \\
\hline Control & $3.75^{\mathrm{d}}$ & $3.50^{\mathrm{d}}$ & $3.62^{\mathrm{c}}$ & $4.75^{\mathrm{c}}$ & $4.50^{\mathrm{c}}$ & $4.62^{\mathrm{b}}$ & $14.25^{\mathrm{c}}$ & $15.25^{\mathrm{bc}}$ & $14.75^{\mathrm{C}}$ & $14.50^{\mathrm{d}}$ & $14.50^{\mathrm{d}}$ & $14.50^{\mathrm{c}}$ \\
\hline Cold water & $4.25^{\mathrm{c}}$ & $4.50^{\mathrm{c}}$ & $4.37^{\mathrm{b}}$ & $4.75^{\mathrm{c}}$ & $5.25^{\mathrm{b}}$ & $5.00^{\mathrm{b}}$ & $13.00^{\mathrm{d}}$ & $13.50^{\mathrm{d}}$ & $13.25^{\mathrm{d}}$ & $15.75^{\mathrm{d}}$ & $14.00^{\mathrm{d}}$ & $13.37^{\mathrm{d}}$ \\
\hline Hot water & $5.25^{\mathrm{b}}$ & $4.00^{c}$ & $4.62^{\mathrm{b}}$ & $4.00^{\mathrm{c}}$ & $4.75^{\mathrm{c}}$ & $4.37^{\mathrm{b}}$ & $12.00^{\mathrm{c}}$ & $12.75^{\mathrm{de}}$ & $12.37^{\mathrm{d}}$ & $12.25^{\mathrm{f}}$ & $11.25^{\mathrm{f}}$ & $11.75^{\mathrm{e}}$ \\
\hline $\mathrm{H}_{2} \mathrm{SO}_{4}$ & $7.50^{\mathrm{a}}$ & $8.75^{\mathrm{a}}$ & $8.12^{\mathrm{a}}$ & $8.75^{\mathrm{a}}$ & $8.25^{\mathrm{a}}$ & $8.50^{\mathrm{a}}$ & $15.75^{\mathrm{bc}}$ & $20.25^{\mathrm{a}}$ & $18.00^{\mathrm{a}}$ & $18.50^{\mathrm{b}}$ & $22.50^{\mathrm{a}}$ & $20.50^{\mathrm{a}}$ \\
\hline $\mathrm{GA}_{3}$ & $4.00^{\mathrm{c}}$ & $5.75^{\mathrm{b}}$ & $4.87^{\mathrm{b}}$ & $3.50^{\mathrm{d}}$ & $6.00^{\mathrm{b}}$ & $4.75^{\mathrm{b}}$ & $15.75^{\mathrm{bc}}$ & $16.75^{\mathrm{b}}$ & $16.25^{\mathrm{b}}$ & $16.25^{\mathrm{c}}$ & $16.25^{\mathrm{c}}$ & $16.25^{\mathrm{b}}$ \\
\hline Acetone & $4.25^{\mathrm{c}}$ & $4.25^{\mathrm{c}}$ & $4.25^{\mathrm{b}}$ & $4.00^{\mathrm{b}}$ & $4.50^{\mathrm{c}}$ & $4.25^{\mathrm{b}}$ & $13.50^{\mathrm{d}}$ & $15.75^{\mathrm{bc}}$ & $14.62^{\mathrm{C}}$ & $15.00^{\mathrm{d}}$ & $16.00^{\mathrm{c}}$ & $15.50^{\mathrm{b}}$ \\
\hline \multirow[t]{2}{*}{ Mean } & $4.83^{\mathrm{a}}$ & $5.12^{\mathrm{a}}$ & & $4.96^{\mathrm{b}}$ & $5.54^{\mathrm{a}}$ & & $14.04^{\mathrm{b}}$ & $15.71^{\mathrm{a}}$ & & $15.37^{\mathrm{b}}$ & $15.75^{\mathrm{a}}$ & \\
\hline & \multicolumn{6}{|c|}{ Root dry weight (g) } & \multicolumn{6}{|c|}{ Root length $(\mathrm{cm})$} \\
\hline Control & $3.45^{\mathrm{g}}$ & $3.27^{\mathrm{g}}$ & $3.36^{\mathrm{f}}$ & $3.33^{\mathrm{j}}$ & $3.55^{\mathrm{i}}$ & $3.43^{\mathrm{e}}$ & $2.52^{g}$ & $2.60^{\mathrm{g}}$ & $2.56^{\mathrm{e}}$ & $2.47^{\mathrm{g}}$ & $2.70^{\mathrm{f}}$ & $2.58^{\mathrm{e}}$ \\
\hline Cold water & $4.61^{\mathrm{e}}$ & $4.22^{\mathrm{f}}$ & $4.42^{\mathrm{e}}$ & $4.25^{\mathrm{g}}$ & $4.04^{\mathrm{h}}$ & $4.14^{\mathrm{d}}$ & $3.30^{\mathrm{c}}$ & $2.95^{\mathrm{d}}$ & $3.12^{\mathrm{c}}$ & $3.12^{\mathrm{d}}$ & $2.80^{\mathrm{f}}$ & $2.96^{\mathrm{c}}$ \\
\hline Hot water & $4.63^{\mathrm{e}}$ & $5.42^{\mathrm{d}}$ & $5.03^{\mathrm{d}}$ & $4.66^{\mathrm{f}}$ & $5.77^{\mathrm{d}}$ & $5.22^{\mathrm{c}}$ & $3.25^{\mathrm{c}}$ & $3.50^{\mathrm{b}}$ & $3.57^{\mathrm{b}}$ & $3.40^{\mathrm{c}}$ & $3.25^{\mathrm{c}}$ & $3.25^{\mathrm{b}}$ \\
\hline $\mathrm{H}_{2} \mathrm{SO}_{4}$ & $7.06^{\mathrm{b}}$ & $7.41^{\mathrm{a}}$ & $7.29^{\mathrm{a}}$ & $7.49^{\mathrm{a}}$ & $6.88^{\mathrm{b}}$ & $7.18^{\mathrm{a}}$ & $3.85^{\mathrm{a}}$ & $3.75^{\mathrm{a}}$ & $3.79^{\mathrm{a}}$ & $3.75^{\mathrm{a}}$ & $3.82^{\mathrm{a}}$ & $3.77^{\mathrm{a}}$ \\
\hline $\mathrm{GA}_{3}$ & $6.43^{\mathrm{c}}$ & $6.21^{\mathrm{c}}$ & $6.33^{\mathrm{b}}$ & $6.33^{\mathrm{c}}$ & $6.29^{\mathrm{c}}$ & $6.31^{\mathrm{b}}$ & $3.10^{\mathrm{d}}$ & $3.47^{\mathrm{b}}$ & $3.29^{\mathrm{b}}$ & $3.25^{\mathrm{c}}$ & $3.52^{\mathrm{b}}$ & $3.38^{\mathrm{b}}$ \\
\hline Acetone & $5.35^{\mathrm{d}}$ & $5.36^{\mathrm{d}}$ & $5.35^{\mathrm{c}}$ & $5.23^{\mathrm{e}}$ & $5.30^{\mathrm{e}}$ & $5.27^{\mathrm{c}}$ & $2.77^{\mathrm{e}}$ & $2.75^{\mathrm{f}}$ & $2.75^{\mathrm{d}}$ & $2.70^{\mathrm{f}}$ & $2.87^{\mathrm{e}}$ & $2.78^{\mathrm{d}}$ \\
\hline Mean & $5.26^{\mathrm{a}}$ & $5.32^{\mathrm{a}}$ & & $5.21^{\mathrm{a}}$ & $5.30^{\mathrm{a}}$ & & $3.13^{\mathrm{a}}$ & $3.16^{\mathrm{a}}$ & & $3.11^{\mathrm{a}}$ & $3.16^{\mathrm{a}}$ & \\
\hline
\end{tabular}

Physical dormancy is an adaptive trait, allowing seed germination over time and space, thus increasing the probability of enhancing the propagation of a species (Baskin and Baskin, 2000). Similar seed dormancy characteristics were reported in Carob by Pérez-García (2009). Seed dormancy can be broken by mechanical scarification and certain pretreatments such as $\mathrm{H}_{2} \mathrm{SO}_{4}$, cold water, hot water $\mathrm{GA}_{3}$ and acetone treatments (ElShatnawi et al., 2001; Karaguzel et al., 2002; Pérez-García, 2009; Piotto and Di Noi, 2003). All pretreatments enhanced the seed resulting in higher germination and good growth in Carob producing seedlings. Consequently, $\mathrm{H}_{2} \mathrm{SO}_{4}, \mathrm{GA}_{3}$ and hot water beside other treatment was found to be superior in terms of germination percentage, average germination time, plant length, number of leaves/plant, root length and root dry weight. However, Pérez-García (2009) used various treatments to enhance seed germination in Carob and found the lowest germination rate in the control seeds and highest (99\%) in scarified seeds. Similarly, Tsakaldimi and Ganatsas (2001) found that the highest germination rate $(87 \%)$ was found on seeds dipped in concentrated acid for 15 minutes but that the shortest average germination time (8 days) was observed with hot water soaking for 5 minutes. In this study, the highest germination percentage and fastest germination time was obtained with $60 \%$ $\mathrm{H}_{2} \mathrm{SO}_{4}$ treatment, but the least mean germination percentage and longest germination time was found using tap water as a control treatment. Piotto and Di Noi (2003) have demonstrated that if Carob seeds had been either soaked in hot water, or dipped in concentrated $\mathrm{H}_{2} \mathrm{SO}_{4}$ and then washed in water, or mechanically scarified, then there is no subsequent problem in terms of seed germination. 


\section{Vegetative propagation by cuttings}

The effects of two dates (April and September) of culture, as a first factor, and concentration of PGRs, as a second factor, on vegetative propagation of Carob by using stem cuttings, under tunnel, were studied. Data illustrated in Table 2 showed great significant differences between treatments for all growth parameters (shoot length, number of lateral shoot, number of leaves/plant, root length, number of roots/plant and root dry weight) of Carob cuttings.

Table 2. Effect of some growth regulators and time of vegetative propagation by stem cuttings, on shoot length, no. of lateral shoot, no. of leaves/plant, root length, no. of roots/plant and root dry weight, of carob during 2011 and 2012 seasons.

\begin{tabular}{|c|c|c|c|c|c|c|c|c|c|c|c|c|}
\hline \multirow{2}{*}{ Treatments } & \multicolumn{3}{|c|}{2011} & \multicolumn{3}{|c|}{2012} & \multicolumn{3}{|c|}{2011} & \multicolumn{3}{|c|}{2012} \\
\hline & April & Sep. & Mean & April & Sep. & Mean & April & Sep. & Mean & April & Sep. & Mean \\
\hline & \multicolumn{6}{|c|}{ Shoot length $(\mathrm{cm})$} & \multicolumn{6}{|c|}{ No. of lateral shoots } \\
\hline Control & $0.00 \mathrm{~s}$ & $0.00 \Xi$ & $0.00^{\circ}$ & $0.00^{\mathrm{a}}$ & $0.00^{=}$ & $0.00^{\mathrm{s}}$ & $0.00 \mathrm{~s}$ & $0.00 \mathrm{~g}$ & $0.00^{\circ}$ & $0.00^{:}$ & $0.00^{2}$ & $0.00^{d}$ \\
\hline $6000 \mathrm{mg} / 1 \mathrm{IBA}$ & $11.00^{f}$ & $0.00 \mathrm{~s}$ & $5.50^{\mathrm{b}}$ & $11.75^{\mathrm{d}}$ & $0.00^{:}$ & $5.87^{\circ}$ & $1.50^{d}$ & 0.008 & $0.75^{\mathrm{c}}$ & $1.75^{\mathrm{d}}$ & $0.00^{:}$ & $0.877^{\circ}$ \\
\hline $8000 \mathrm{mg} / 1 \mathrm{IBA}$ & $13.00^{2}$ & $0.00 \mathrm{~s}$ & $6.50^{\mathrm{b}}$ & $13.00^{\circ}$ & $0.00^{2}$ & $6.50^{b}$ & $1.75^{\mathrm{d}}$ & $0.00 g$ & $0.78^{\circ}$ & $2.00^{\mathrm{d}}$ & $0.00^{2}$ & $1.00^{\circ}$ \\
\hline $6000 \mathrm{mg} / 1 \mathrm{IBA}+200 \mathrm{mg} / 1 \mathrm{NAA}$ & $17.25^{\circ}$ & $16.25^{b}$ & $16.75^{\mathrm{a}}$ & $15.75^{\circ}$ & $16.75^{\circ}$ & $16.25^{\mathrm{a}}$ & $3.50^{\circ}$ & $5.00^{\mathrm{a}}$ & $4.25^{\mathrm{a}}$ & $4.00^{\circ}$ & $4.75^{\circ}$ & $4.37^{\circ}$ \\
\hline $8000 \mathrm{mg} 1 \mathrm{IBA}+200 \mathrm{mg} / 1 \mathrm{NAA}$ & $18.25^{b}$ & $19.25^{\mathrm{a}}$ & $18.75^{\mathrm{a}}$ & $19.00^{\mathrm{3}}$ & $18.75^{\mathrm{a}}$ & $18.87^{\mathrm{a}}$ & $5.25^{\mathrm{a}}$ & $4.75^{\mathrm{a}}$ & $5.00^{\mathrm{a}}$ & $5.50^{\mathrm{a}}$ & $5.50^{\mathrm{a}}$ & $5.50^{\mathrm{a}}$ \\
\hline Radecant $80 \%$ & $10.75^{i}$ & $0.00 \mathrm{~g}$ & $5.37^{\circ}$ & $12.75^{d}$ & $0.00^{z}$ & $6.37^{\circ}$ & $2.50^{\circ}$ & $0.00 \mathrm{~g}$ & $1.25^{b}$ & $2.25^{\mathrm{d}}$ & $0.00^{2}$ & $1.12^{\circ}$ \\
\hline \multirow[t]{2}{*}{ Mean } & $11.71^{\mathrm{3}}$ & $5.91^{b}$ & & $12.04^{3}$ & $5.91^{b}$ & & $2.41^{\mathrm{3}}$ & $1.62^{b}$ & & $2.58^{\mathrm{a}}$ & $1.70^{b}$ & \\
\hline & \multicolumn{6}{|c|}{ No. of leaves plant } & \multicolumn{6}{|c|}{ Root length $(\mathrm{cm})$} \\
\hline Control & $0.00^{:}$ & $0.00^{:}$ & $0.00^{\circ}$ & $0.00^{d}$ & $0.00^{d}$ & $0.00^{\circ}$ & $0.00^{:}$ & $0.00^{:}$ & $0.00^{d}$ & $0.00^{\circ}$ & $0.00^{:}$ & $0.00^{\circ}$ \\
\hline $6000 \mathrm{mg} 1 \mathrm{IBA}$ & $3.50^{\mathrm{d}}$ & $0.00^{\mathrm{a}}$ & $1.75^{b}$ & $4.00^{\circ}$ & $0.00^{d}$ & $2.00^{\circ}$ & $5.55^{\mathrm{d}}$ & $0.00^{:}$ & $2.77^{\circ}$ & $5.70^{\circ}$ & $0.00^{:}$ & $2.85^{b}$ \\
\hline $8000 \mathrm{mg} / 1 \mathrm{IBA}$ & $4.00^{\circ}$ & $0.00^{\mathrm{s}}$ & $2.00^{\circ}$ & $3.50^{\circ}$ & $0.00^{\mathrm{d}}$ & $1.75^{\circ}$ & $5.35^{\mathrm{d}}$ & $0.00^{\mathrm{s}}$ & $2.67^{\circ}$ & $5.05^{\mathrm{d}}$ & $0.00^{2}$ & $2.52^{b}$ \\
\hline $6000 \mathrm{mg} / 1 \mathrm{IBA}+200 \mathrm{mg} / 1 \mathrm{NAA}$ & $4.25^{\circ}$ & $4.75^{b}$ & $4.50^{\mathrm{a}}$ & $4.00^{\circ}$ & $5.00^{\circ}$ & $4.50^{\mathrm{a}}$ & $5.80^{\circ}$ & $6.07^{b}$ & $5.93^{b}$ & $5.80^{\circ}$ & $6.57^{b}$ & $6.18^{\mathrm{a}}$ \\
\hline $8000 \mathrm{mg} / \mathrm{IBA}+200 \mathrm{mg} / \mathrm{NAA}$ & $5.50^{\mathrm{a}}$ & $5.75^{\mathrm{a}}$ & $5.62^{\mathrm{a}}$ & $5.50^{\mathrm{a}}$ & $5.75^{\mathrm{a}}$ & $5.62^{\mathrm{a}}$ & $7.57^{\mathrm{a}}$ & $7.50^{\mathrm{a}}$ & $7.53^{\mathrm{a}}$ & $7.55^{\mathrm{a}}$ & $7.37^{\mathrm{a}}$ & $7.46^{\mathrm{a}}$ \\
\hline Radecant $80 \%$ & $3.75^{6}$ & $0.00^{\mathrm{z}}$ & $1.87^{\circ}$ & $4.25^{\mathrm{b}}$ & $0.00^{\mathrm{d}}$ & $2.12^{b}$ & $5.45^{\mathrm{d}}$ & $0.00^{\mathrm{z}}$ & $2.72^{\circ}$ & $5.57^{\circ}$ & $0.00^{2}$ & $2.78^{b}$ \\
\hline \multirow[t]{2}{*}{ Mean } & $3.50^{\mathrm{a}}$ & $1.75^{b}$ & & $3.54^{\mathrm{a}}$ & $1.79^{\circ}$ & & $4.95^{\mathrm{a}}$ & $2.26^{\circ}$ & & $4.94^{\mathrm{a}}$ & $2.32^{b}$ & \\
\hline & \multicolumn{6}{|c|}{ No. of roots plant } & \multicolumn{6}{|c|}{ Root dry weight (g) } \\
\hline Control & $0.00 \mathrm{~g}$ & $0.00 \mathrm{~s}$ & $0.00^{\mathrm{d}}$ & $0.00^{f}$ & $0.00^{f}$ & $0.00^{d}$ & $0.00 \Omega$ & $0.00 \mathrm{~s}$ & $0.00^{:}$ & $0.00^{\mathrm{h}}$ & $0.00^{\mathrm{h}}$ & $0.00^{d}$ \\
\hline $6000 \mathrm{mg} / 1 \mathrm{IBA}$ & $4.34^{f}$ & $0.00 \mathrm{~s}$ & $2.17^{\circ}$ & $4.51^{\mathrm{s}}$ & $0.00^{f}$ & $2.25^{c}$ & $3.50^{f}$ & $0.00 \mathrm{~g}$ & $1.65^{\mathrm{d}}$ & $3.57 \mathrm{~g}$ & $0.00^{\mathrm{h}}$ & $1.78^{\circ}$ \\
\hline $8000 \mathrm{mg} 1 \mathrm{IBA}$ & $5.39:$ & $0.00 \mathrm{~g}$ & $2.69^{\circ}$ & $5.32^{\mathrm{d}}$ & $0.00^{f}$ & $2.66^{\circ}$ & $4.39 \mathrm{~s}$ & $0.00 \Xi$ & $2.19^{\circ}$ & $4.24^{f}$ & $0.00^{\mathrm{h}}$ & $2.12^{\circ}$ \\
\hline $6000 \mathrm{mg} / 1 \mathrm{IBA}+200 \mathrm{mg} / 1 \mathrm{NAA}$ & $6.44^{d}$ & $7.34^{\circ}$ & $6.89^{\circ}$ & $6.28^{\circ}$ & $7.42^{\circ}$ & $6.85^{\circ}$ & $4.66^{d}$ & $4.62^{d}$ & $4.64^{b}$ & $4.66^{\mathrm{d}}$ & $4.46^{2}$ & $4.56^{b}$ \\
\hline $8000 \mathrm{mg} / \mathrm{IBA}+200 \mathrm{mg} / 1 \mathrm{NAA}$ & $8.16^{2}$ & $9.45^{\mathrm{a}}$ & $8.80^{3}$ & $8.92^{\mathrm{a}}$ & $8.35^{\mathrm{a}}$ & $8.64^{\mathrm{a}}$ & $7.08^{\circ}$ & $7.62^{\mathrm{a}}$ & $7.37^{\mathrm{a}}$ & $7.49^{\mathrm{s}}$ & $6.83^{b}$ & $7.16^{\mathrm{a}}$ \\
\hline Radecant $80 \%$ & $6.20^{d}$ & $0.00^{\ddagger}$ & $3.10^{6}$ & $6.63^{6}$ & $0.00^{f}$ & $3.31^{\mathrm{c}}$ & $6.51^{\mathrm{c}}$ & $0.00 \mathrm{~g}$ & $3.26^{\mathrm{t}}$ & $6.36^{\circ}$ & $0.00^{\mathrm{h}}$ & $3.18^{\circ}$ \\
\hline Mean & $5.30^{\mathrm{a}}$ & $2.58^{\circ}$ & & $5.28^{\mathrm{a}}$ & $2.63^{\circ}$ & & $4.32^{3}$ & $2.04^{b}$ & & $4.38^{\mathrm{a}}$ & $1.88^{\circ}$ & \\
\hline
\end{tabular}

Regarding the effect of different PGRs treatments on all the studied parameters of cuttings, it is obvious that all treatments positively affect these parameters, compared with the control treatment, in both seasons. It can be clearly noticed in Tables 2 that the best treatments, which gave the highest values of shoot length, no. of lateral shoot, no. of leaves/plant, root length, no. of roots/plant and root dry weight, were IBA at $8000 \mathrm{mg} / \mathrm{l}+\mathrm{NAA}$ at $200 \mathrm{mg} / \mathrm{l}(18.75$ and $18.87 \mathrm{~cm}, 5.00$ and 5.50, 5.62, 7.53 and $7.46 \mathrm{~cm}, 8.80$ and $8.64,7.37$ and $7.16 \mathrm{~g}$, respectively), compared with the control and other treatments in both 2011 and 2012 seasons.

On the other hand, April was found the best time for the treated Carob cuttings for all treatments compared with September, in both 2011 and 2012 seasons. It was clear that treated cuttings showed, in general, the significantly best and highest values of all tested parameters in April. While, in September, treated cuttings failed to root with all treatments, except when cuttings were treated with IBA at $6000 \mathrm{mg} / \mathrm{l}+\mathrm{NAA}$ at $200 \mathrm{mg} / \mathrm{l}$ and IBA at $8000 \mathrm{mg} / \mathrm{l}+\mathrm{NAA}$ at $200 \mathrm{mg} / \mathrm{l}$, in 2011 and 2012 seasons.

Regarding, the interaction, data clearly showed that Carob cuttings treated with IBA at $8000 \mathrm{mg} / \mathrm{l}+$ NAA at $200 \mathrm{mg} / \mathrm{l}$, followed by cuttings treated with IBA at $6000 \mathrm{mg} / \mathrm{l}+\mathrm{NAA}$ at $200 \mathrm{mg} / \mathrm{l}$ gave the highest values of parameters, in April and September, in both seasons. While, in September, treated cutting failed to root for all treatments, except when cuttings were treated with IBA at $6000 \mathrm{mg} / \mathrm{l}+\mathrm{NAA}$ at $200 \mathrm{mg} / \mathrm{l}$ and IBA at $8000 \mathrm{mg} / \mathrm{l}+\mathrm{NAA}$ at $200 \mathrm{mg} / \mathrm{l}$, in the two studied seasons.

These results were in agreement with the findings of Çelik et al. (1994) and Ibrahim et al. (2009) on olive. Plastic tunnels with water mist gave the best rooting and vegetative growth, followed by the cuttings under plastic tunnel without mist in Hamelia patens (Elgimabi, 2009). Loach (1997) studied the leaf water potential and the rooting of cuttings of Rhododendron under mist and polythene. He stated that propagation under polythene gave better results than mist in the lower radiation conditions. He studied also the variation in water potential in cuttings under mist and polythene and found that cuttings in mist depended on three variables namely; current days radiation, number of days from insertion of cuttings and the previous days leaf water potential, which was relatively unimportant, probably because cuttings were able to take up water over night from condensation on the under surface of the polythene. 


\section{Micropropagation \\ Culture establishment}

MS basal medium supplemented with various cytokinins in addition to NAA showed that shoots could initiate from shoot tips and stem node segments of Carob on all the tested media. The percentage of explants initiating growth reached 100\% (Tables 3 and 4, Figures 5A and B). Concerning the in vitro establishment of shoot tips (Table 3), data obtained after 8 weeks of culture revealed that shoots could be induced on all tested media with $100 \%$ growth percentage. MS medium supplemented with $0.4 \mathrm{mg} / \mathrm{l} \mathrm{NAA}+2.0 \mathrm{mg} / \mathrm{l} \mathrm{BAP}$ gave the significantly highest number of shoots (3.0 shoots/explant), but with a length of only $0.6 \mathrm{~cm}$ (Figure 5A). Followed by the medium containing $0.4 \mathrm{mg} / 1 \mathrm{NAA}+0.5 \mathrm{mg} / \mathrm{l} 2 \mathrm{iP}$, which gave 2.0 shoots/explant, with the significantly highest shoot length $(1.18 \mathrm{~cm})$.

Table 3. Effect of different cytokinins in combination with NAA on the in vitro establishment of shoot tips of Carob.

\begin{tabular}{|c|c|c|c|}
\hline Medium composition & $\begin{array}{l}\text { Growth } \\
\%\end{array}$ & $\begin{array}{l}\text { Mean no. of } \\
\text { shoots/ explant }\end{array}$ & $\begin{array}{ll}\begin{array}{l}\text { Mean } \\
\text { of }\end{array} & \text { length } \\
\text { shoots } \\
(\mathrm{cm})\end{array}$ \\
\hline MS control medium & 100 & $1.00^{\mathrm{c}}$ & $0.42^{\mathrm{de}}$ \\
\hline MS medium $+0.4 \mathrm{mg} / 1 \mathrm{NAA}+0.50 \mathrm{mg} / \mathrm{l} \mathrm{BAP}$ & 100 & $1.33^{\mathrm{c}}$ & $0.70^{\mathrm{bc}}$ \\
\hline MS medium+0.4 mg/l NAA+1.00 mg/l BAP & 100 & $1.33^{\mathrm{c}}$ & $0.88^{\mathrm{b}}$ \\
\hline MS medium+0.4 mg/l NAA+2.00 mg/l BAP & 100 & $3.00^{\mathrm{a}}$ & $0.60^{\mathrm{cd}}$ \\
\hline MS medium+0.4 mg/l NAA+0.50 mg/1 2iP & 100 & $2.00^{\mathrm{b}}$ & $1.18^{\mathrm{a}}$ \\
\hline MS medium+0.4 mg/l NAA+1.00 mg/1 2iP & 100 & $1.00^{\mathrm{c}}$ & $0.78^{\mathrm{bc}}$ \\
\hline MS medium+0.4 mg/l NAA+2.00 mg/1 2iP & 100 & $1.00^{\mathrm{c}}$ & $0.60^{\mathrm{cd}}$ \\
\hline MS medium+0.4 mg/l NAA+0.25 mg/l TDZ & 100 & $1.00^{\mathrm{c}}$ & $0.26^{\mathrm{ef}}$ \\
\hline MS medium+0.4 mg/l NAA+0.50 mg/l TDZ & 100 & $1.67^{\mathrm{bc}}$ & $1.10^{\mathrm{a}}$ \\
\hline MS medium+0.4 mg/l NAA+1.00 mg/l TDZ & 100 & $1.33^{\mathrm{c}}$ & $0.58^{\mathrm{cd}}$ \\
\hline MS medium+0.4 mg/l NAA+2.00 mg/l TDZ & 100 & $1.00^{\mathrm{c}}$ & $0.20^{f}$ \\
\hline
\end{tabular}

Decreasing concentration of BAP brought about a significant decrease in the number of shoots. Although $0.5 \mathrm{mg} / \mathrm{l} 2 \mathrm{iP}$ produced the highest length of shoots, increasing $2 \mathrm{iP}$ concentration significantly decreased the shoot length and also the number of shoots. TDZ gave the least response in terms of the number of shoots, compared to the other used cytokinins (BAP and 2iP), however, MS medium containing $0.4 \mathrm{mg} / \mathrm{l} \mathrm{NAA}$ $+0.5 \mathrm{mg} / 1 \mathrm{TDZ}$ gave significantly high shoot length $(1.1 \mathrm{~cm})$. The control MS medium without PGRs gave only one shoot with a length of $0.42 \mathrm{~cm}$.

Regarding the in vitro establishment of stem node segments of Carob (Table 4), the maximum shoot number (2.6 shoots/explant) was produced on MS medium containing $0.4 \mathrm{mg} / \mathrm{l} \mathrm{NAA}+2.0 \mathrm{mg} / \mathrm{l} \mathrm{BAP}$ (Figure $5 \mathrm{~B})$, followed by the other concentrations of BAP $(0.5$ and $1 \mathrm{mg} / \mathrm{l})$, which produced 1.8 shoots/explant. The other used cytokinins (2iP and TDZ) gave the least response regarding to the number of shoots, even when compared to the control. This result is in harmony with that obtained by Hakim et al. (2010) who found that multiple shoots of Carob were regenerated when explants were cultured on MS medium fortified with BAP with an auxin. By taking into consideration the stem length, it was found that among the concentrations tested, the control MS medium produced the significantly highest length of shoots $(1.5 \mathrm{~cm})$, followed by lengths of shoots of 1.4 and $1.2 \mathrm{~cm}$ on MS medium containing $0.4 \mathrm{mg} / \mathrm{l} \mathrm{NAA}+2.0$ and $1.0 \mathrm{mg} / \mathrm{l} 2 \mathrm{iP}$, respectively. TDZ didn't enhance the elongation of shoots at all tested concentrations compared to the control MS medium or the application of 2iP. Romano et al. (2002) found that shoot culture initiation of Carob is greatly influenced by explanting season. In conclusion, the best in vitro establishment of both tested explants of Carob was induced on MS medium contained the combination of $0.4 \mathrm{mg} / \mathrm{l} \mathrm{NAA}+2.0 \mathrm{mg} / \mathrm{l} \mathrm{BAP}$. This result agrees with Radi et al. (2013) who reported that the concentration of auxin and the balance between the concentration of auxin and cytokinin affected the organogenic potentiality of Carob.

Table 4. Effect of different cytokinins in combination with NAA on the in vitro establishment of stem segments of Carob.

\begin{tabular}{|c|c|c|c|}
\hline Medium composition & $\begin{array}{l}\text { Growth } \\
\%\end{array}$ & $\begin{array}{l}\text { Mean no. of } \\
\text { shoots/ explant }\end{array}$ & $\begin{array}{l}\text { Mean length } \\
\text { of shoots }(\mathrm{cm})\end{array}$ \\
\hline MS medium + $0.4 \mathrm{mg} / \mathrm{l} \mathrm{NAA}+0.50 \mathrm{mg} / \mathrm{l} \mathrm{BAP}$ & 100 & $1.8^{\mathrm{b}}$ & $0.88^{\mathrm{cd}}$ \\
\hline $\mathrm{MS}$ medium $+0.4 \mathrm{mg} / \mathrm{l} \mathrm{NAA}+2.00 \mathrm{mg} / \mathrm{l} \mathrm{BAP}$ & 100 & $2.6^{\mathrm{a}}$ & $0.84^{\mathrm{cd}}$ \\
\hline $\mathrm{MS}$ medium + $0.4 \mathrm{mg} / 1 \mathrm{NAA}+0.50 \mathrm{mg} / 12 \mathrm{iP}$ & 100 & $1.0^{\mathrm{c}}$ & $0.84^{\text {cd }}$ \\
\hline $\mathrm{MS}$ medium $+0.4 \mathrm{mg} / \mathrm{l} \mathrm{NAA}+1.00 \mathrm{mg} / \mathrm{l} 2 \mathrm{iP}$ & 100 & $1.2^{\mathrm{bc}}$ & $1.20^{\mathrm{abc}}$ \\
\hline MS medium $+0.4 \mathrm{mg} / \mathrm{l} \mathrm{NAA}+0.25 \mathrm{mg} / \mathrm{l} \mathrm{TDZ}$ & 100 & $1.0^{\mathrm{c}}$ & $0.88^{\mathrm{cd}}$ \\
\hline MS medium + $0.4 \mathrm{mg} / \mathrm{l} \mathrm{NAA}+0.50 \mathrm{mg} / \mathrm{l} \mathrm{TDZ}$ & 100 & $1.0^{\mathrm{c}}$ & $0.68^{\mathrm{d}}$ \\
\hline MS medium + $0.4 \mathrm{mg} / \mathrm{l} \mathrm{NAA}+1.00 \mathrm{mg} / \mathrm{l} \mathrm{TDZ}$ & 100 & $1.0^{\mathrm{c}}$ & $0.56^{\mathrm{d}}$ \\
\hline MS medium + $0.4 \mathrm{mg} / \mathrm{l} \mathrm{NAA}+2.00 \mathrm{mg} / \mathrm{l} \mathrm{TDZ}$ & 100 & $1.2^{\mathrm{bc}}$ & $0.94^{\text {bcd }}$ \\
\hline
\end{tabular}




\section{Shoot multiplication and elongation}

Shoot multiplication rates were not significantly affected by the concentration of BAP or $2 \mathrm{iP}$, as up to 3.8 shoots/explant were recorded using $1.0 \mathrm{mg} / \mathrm{l} \mathrm{BAP}$, which was the highest value. This result agrees with that of Romano et al. (2002) who obtained the best multiple-shoot response with Mulata Carob cultivar on MS medium supplemented with BAP. The longest shoots of 1.4 and $1.28 \mathrm{~cm}$ were obtained on MS medium containing 1.0 and $0.5 \mathrm{mg} / \mathrm{l} 2 \mathrm{iP}$, respectively, followed by the higher $2 \mathrm{iP}$ concentration $(2.0 \mathrm{mg} / \mathrm{l})$ and the control treatment (Table 5).

Table 5. Influence of BAP or 2iP individually on the multiplication of Carob shoots

\begin{tabular}{|l|l|l|l|}
\hline Medium composition & Growth \% & $\begin{array}{l}\text { Mean no. of shoots/ } \\
\text { explant }\end{array}$ & $\begin{array}{l}\text { Mean length of } \\
\text { shoots (cm) }\end{array}$ \\
\hline MS control medium & 100 & $1.4^{\mathrm{c}}$ & $0.84^{\mathrm{b}}$ \\
\hline MS medium + 0.5 mg/l BAP & 100 & $3.2^{\mathrm{ab}}$ & $0.70^{\mathrm{bc}}$ \\
\hline MS medium + 1.0 mg/l BAP & 100 & $3.8^{\mathrm{a}}$ & $0.58^{\mathrm{bc}}$ \\
\hline MS medium + 2.0 mg/l BAP & 100 & $2.6^{\mathrm{abc}}$ & $0.46^{\mathrm{c}}$ \\
\hline MS medium + 3.0 mg/l BAP & 100 & $2.6^{\mathrm{abc}}$ & $0.38^{\mathrm{c}}$ \\
\hline MS medium + 0.5 mg/l 2iP & 100 & $2.6^{\mathrm{abc}}$ & $1.28^{\mathrm{a}}$ \\
\hline MS medium + 1.0 mg/l 2iP & 100 & $2.4^{\mathrm{abc}}$ & $1.40^{\mathrm{a}}$ \\
\hline MS medium + 2.0 mg/l 2iP & 100 & $2.2^{\mathrm{abc}}$ & $0.92^{\mathrm{b}}$ \\
\hline MS medium + 3.0 mg/l 2iP & 100 & $2.0^{\mathrm{bc}}$ & $0.64^{\mathrm{bc}}$ \\
\hline
\end{tabular}

Effect of the combination of BAP and 2iP on the shoots multiplication and elongation was studies and represented in Table 6. It was found that the combination of the two cytokinins enhanced both the multiplication and elongation of in vitro produced Carob shoots. The highest mean number of shoots (8.6 and 7.2 shoots/explant) was observed on MS medium containing $1.0 \mathrm{mg} / \mathrm{l} \mathrm{BAP}+0.5 \mathrm{mg} / \mathrm{l} 2 \mathrm{iP}$ (Figure 5C and D) and $0.5 \mathrm{mg} / \mathrm{l} \mathrm{BAP}+0.5 \mathrm{mg} / \mathrm{l} 2 \mathrm{iP}$, with also the significantly highest mean shoots length of 2.3 and $2.54 \mathrm{~cm}$, respectively. Increasing the concentration of $2 \mathrm{iP}$ to $1.0 \mathrm{mg} / \mathrm{l}$ in addition to BAP (at $0.5 \mathrm{or} 1.0 \mathrm{mg} / \mathrm{l}$ ) decreased both number and length of shoots. Romano et al. (2002) reported that for Carob cultivar, cytokinin type and concentration are the most important factors affecting shoots multiplication.

Table 6. Influence of BAP in combination with 2iP on multiplication and elongation of Carob shoots

\begin{tabular}{|l|l|l|l|}
\hline Medium composition & Growth \% & $\begin{array}{l}\text { Mean no. of } \\
\text { shoots/explant }\end{array}$ & $\begin{array}{l}\text { Mean length of } \\
\text { shoots }(\mathrm{cm})\end{array}$ \\
\hline MS control medium & 100 & $1.0^{\mathrm{c}}$ & $0.70^{\mathrm{c}}$ \\
\hline MS medium $+0.5 \mathrm{mg} / \mathrm{l} \mathrm{BAP}+0.5 \mathrm{mg} / \mathrm{l} 2 \mathrm{iP}$ & 100 & $7.2^{\mathrm{a}}$ & $2.54^{\mathrm{a}}$ \\
\hline MS medium $+1.0 \mathrm{mg} / \mathrm{BAP}+0.5 \mathrm{mg} / 12 \mathrm{iP}$ & 100 & $8.6^{\mathrm{a}}$ & $2.30^{\mathrm{ab}}$ \\
\hline MS medium $+0.5 \mathrm{mg} / \mathrm{l} \mathrm{BAP}+1.0 \mathrm{mg} / 12 \mathrm{iP}$ & 100 & $3.2^{\mathrm{b}}$ & $2.00^{\mathrm{abc}}$ \\
\hline MS medium $+1.0 \mathrm{mg} / 1 \mathrm{BAP}+1.0 \mathrm{mg} / 12 \mathrm{iP}$ & 100 & $2.2^{\mathrm{b}}$ & $1.60^{\mathrm{bc}}$ \\
\hline
\end{tabular}

The rooting of Carob shoots was very difficult, as all the tested treatments gave negative results, although, the reported superior effect of IBA over other auxins, which may be due to its slow movement and slow degradation. Previous studies demonstrated that the hormonal concentration in the shoot culture medium might have a carryover effect on rooting (McComb, 1995). Also, the explants may contain endogenous auxin in addition to the added concentration, which could be supra-optimum for them to induce rooting. It has been repeatedly confirmed that auxin is required for initiation of adventitious roots on stems and the development of the first initial root cells is dependent upon either the added or the endogenous auxins (Pignatti and Crobeddu, 2005 and Radi et al., 2013). Carob has been described as one of the most difficult species to root (Lee et al., 1977; Hartman and Kester, 1983 and Gubbuk et al., 2011). Since the Carob traditional propagation methods failed to meet the market request, the use of micropropagtion seems to be appropriate in order to fulfill the increasing demand of this valuable species (Romano et al., 2002).

In conclusion, this study describes three successful methods for the propagation of Carob, as one of the environmentally and economically important species. Although, the in vitro establishment and multiple shoots production gave positive results, the micropropagtion of this plant needs further studies to overcome the difficulties in the root induction. 

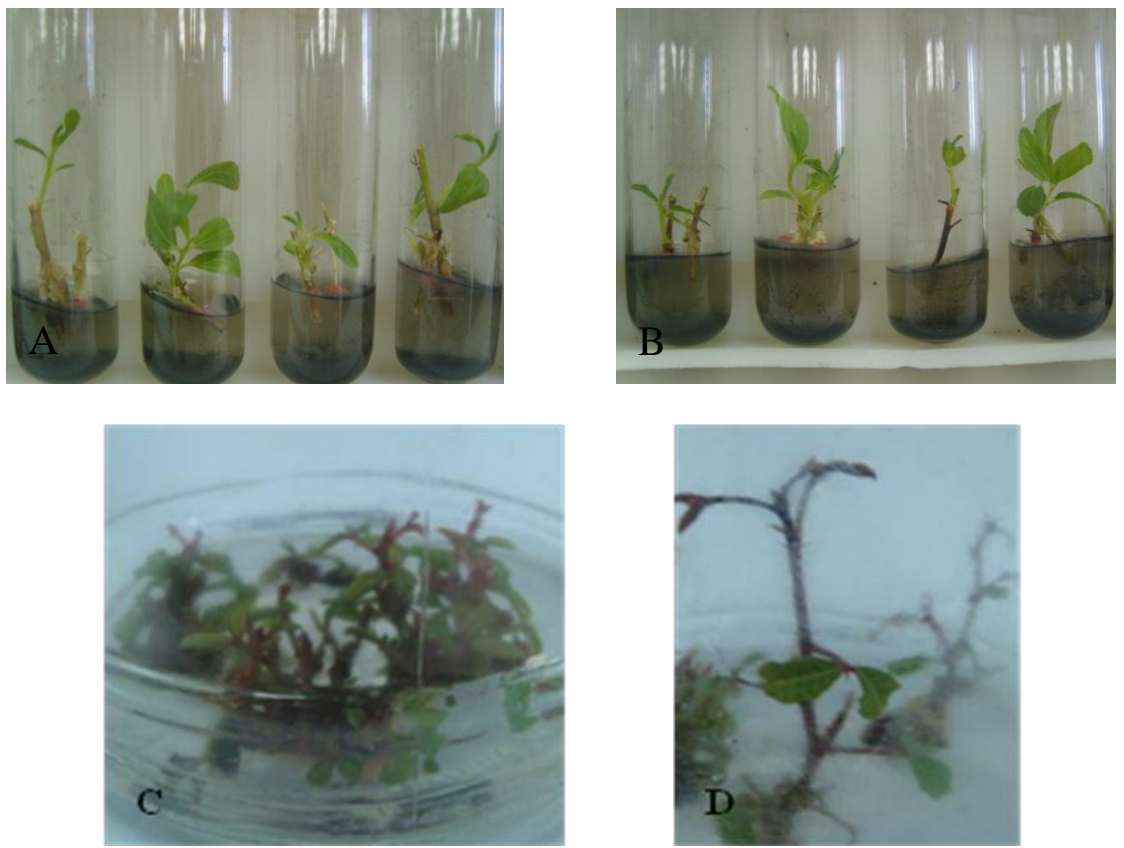

Figure 5. Micropropagation of Carob. In vitro establishment of (A) shoot tips and (B) stem node sections on MS medium containing $0.4 \mathrm{mg} / \mathrm{l} \mathrm{NAA}+2.0 \mathrm{mg} / \mathrm{l} \mathrm{BAP}$.

(C) Multiplication and (D) elongation of shoots on MS medium containing $1.0 \mathrm{mg} / \mathrm{l} \mathrm{BAP}+0.5 \mathrm{mg} / \mathrm{l} 2 \mathrm{iP}$.

\section{References}

[1]. Alorda M., Estodes J., Galmes J. and Medrano H. 1987. Promotion of rooting in Carob cuttings. Gartenbauwissenschaft, Valencia, Spain, 52(1): 31-34.

[2]. Anonymous 2009. http://www.fao.org.

[3]. Baskin J.M. and Baskin C.C. 2000. Evolutionary considerations of claims for physical dormancy-break by microbial action and abrasion by soil particles. Seed Sci. Res., 10: 409-413.

[4]. Battle I. and Tous J. 1997. Carob tree. Ceratonia siliqua L. Promoting the Conservation and Use of Under-Utilised and Neglected Crops 17. Institute of Plant Genetics and Crop Plant Research, Gatersleben/ International Plant Genetic Resources Institute, Rome, Italy, pp. 93

[5]. Cabrita R.J.M., Graca L.S. and Martins-Loucâo A.M. 1988. Evaluation of parameters affecting the rooting of Hardwood cuttings in Ceratonia siliqua L. pp.237-244 in proceedings of the international Carob symposium (P. Fito and A. Mulet, eds.). Valencia, Spain.

[6]. Çelik M., Özkaya M.T. and Dumanoglu H. 1994. The research on possibilities of using the shaded polyethylene tunnels (spt) for the rooting of olive (Olea europaea L.). Acta Hort., 356: II International Symposium on Olive Growing.

[7]. Duncan D.B. 1955. Multiple ranges and multiple F-test Biometrics, 11: 1-24.

[8]. El-Shafey Y.H., Elshihy O.M., Youssef, E.M. and Mervat M. Gad 1998. Production of Ceratonia siliqua female plantlets through tissue culture technique. Arab J. Biotech., 1(1): 77-85.

[9]. El-Shatnawi M.K. and Ereifej K.I. 2001. Chemical composition and livestock ingestion of Carob (Ceratonia siliqua L.) seeds. J. Range Manage., 54: 669-673.

[10]. Esma G., Hamide G. and Dilek Y. 2009. The effect of different sulfuric acid concentrations on seed germination of Carob (Ceratonia siliqua L.). Bull. UASVM Hort., 66(1).

[11]. Elgimabi M.N. 2009. Improvement of propagation by hardwood cuttings with or without using plastic tunnel in (Hamelia patens). World J. Agric. Sci., 5(5): 522-52.

[12]. George E.F. 1993. Plant Propagation by Tissue Culture. Part 2. In Practise. $2^{\text {nd }}$ edn. Exegetics Limited, Edington, pp. 579-581

[13]. Gerakakis A.C. and Ozkaya M.T. 2005. Effects of cutting size, rooting media and planting time on rooting of Domat and Ayvali live (Olea europea L.) cultivars in shaded polyethylene tunnel (Spt). Tarim Bilim. Derg., 11(3): 334- 338.

[14]. Gubbuk H., Gunes E., Ayala-Silva T. and Ercisli S. 2011. Rapid vegetative propagation method for Carob. Not. Bot. Hort. Agrobot. Cluj., 39(1): 251-254.

[15]. Hakim L., Islam M.R., Mamun A.N.K., Ahmed G. and Khan R. 2010. Clonal propagation of Carob (Ceratonia siliqua L., Fabaceae). Bangladesh J. Bot., 39(1): 15-19.

[16]. Hartmann H.T. and Kester D.E. 1983. Plant Propagation, Principles and Practices, 4 Ed., Prentice Hall, New York, USA, pp. 265268.

[17]. Hartmann H.T., Kester D.E., Davies F.T. and Geneve R.L. 2002. Plant Propagation Principles and Practices, $6^{\text {th }}$ ed., Prentice Hall of India Pvt. Ltd., New Delhi, India.

[18]. Ibrahim M., Osman S., Emad G. M. and Adel M.G. (2009). Effect of rooting media and planting time on rooting of Manzanillo and Coratina olive (Olea europaea L.) cultivars under shaded. Smoalia Republic New Bull., 35(2): 261-271

[19]. Janick J. and Paull R.E. 2008. The Encyclopedia of Fruit and Nuts. CABI Publishing, pp. 954.

[20]. Karaguzel O., Baktir I., Cakmakci S., Ortacesme V., Aydınoglu B. and Atik M. 2002. Effects of scarification methods, temperature and sowing date on some germination characteristics of Lupinus varius L. $2^{\text {nd }}$ National Congress on Ornamental Plants, October $22-$ 24, Citrus and Greenhouse Research Institute, Antalya, Turkey, pp. 40-47.

[21]. Laubscher C.P. and Ndakidemi P.A. 2008. The effect of indole acetic acid growth regulator and rooting mediums on rooting of Leucadendron laxum (Proteaceae) in a shade tunnel environment. Am. Eurasian J. Agric. Environ. Sci., 4(3): 326-331. 
[22]. Lee C.L., Paul J.L. and Hackett W.P. 1977. Promoting of rooting in stem cuttings of several ornamental plants by pretreatment with acid or base. HortSci., 12: 41-42.

[23]. Loach 1997. Promoting of rooting in stem cuttings of several ornamental plants. .HortSci., 12(1):41- 42 .

[24]. Manan A.M., Khan A., Ahmad W. and Sattar A. 2002. Clonal Propagation of Guava (Psidium guajava L.). Int. J. Agri. Biol., 4(1).

[25]. Martins-Louçao M.A., Duarte P.J. and Cruz C. 1996. Phenological and physiological studies during Carob (Ceratonia siliqua L.) seed germination. Seed Sci. Technol., 24: 33-47.

[26]. McComb, J.A. 1995. Clonal Propagation of Eucalyptus. In Plant Tissue Culture Manual. Vol. C8. Kluwer Academic Publishers, Dordrecht, pp.1-24.

[27]. Murashige T. and Skoog F. 1962. A revised medium for rapid growth and bioassays with tobacco tissue cultures. Physiol. Plant., 15,485 .

[28]. Pérez-García F. 2009. Germination characteristics and intrapopulation variation in Carob (Ceratonia siliqua L.) seeds. Spanish J. Agric. Res., 7(2): 398-406.

[29]. Pignatti G. and Crobeddu, S. 2005. Effects of rejuvenation on cuttings propagation of Mediterranean shrub species. Forest@ Rivista di Selvicoltura ed Ecologia Forestale, 2(3):290-295.

[30]. Piotto B. and Di Noi A. 2003. Seed Propagation of Mediterranean Trees and Shrubs. Agenzia Nazionale per la Protezione dell'Ambiente (ANPA). Roma, Italy.

[31]. Radi A., Echchgadda G., Ibijbijen J. and Rochd M. 2013. In vitro propagation of Moroccan carob (Ceratonia siliqua L.). J. Food Agri. Environ., 11(1): 1103-1107.

[32]. Romano H., Barros S. and Martins-Loucao M. 2002. Micropropagation of Mediterranean tree Ceratonia siliqua L. Plant Cell Tissue Organ Cult., 68: 35-41.

[33]. Sayed W.T., EL- Taweel A.A. and Madlen R.S. 2010. Study on vegetative propagation of Jojoba. J. Plant Prod., Mansoura Univ., 1(12): 1605-1623.

[34]. Sebastian K.T. and McComb J.A. 1986. A micropropagation system of Carob (Ceratonia siliqua L.) Scienta-Hort., 28(1/2): 127131 .

[35]. Shereen A. Shaheen and Aly A.A. 2011. Comparative studies on some factors affecting rooting ability of Carob stem cuttings. J. Am. Sci., 7(8).

[36]. Snedecor G.W. and Cochron W.G. 1998. Statistical Methods. Iowa State Univ. Press, Ames, Iowa, USA.

[37]. Tsakaldimi M. and Ganatsas P. 2001. Treatments improving seeds germination of two Mediterranean sclerophyll species Ceratonia siliqua and Pistacia lentiscus. In: Proceedings of the Third Balkan Scientific Conference on Study, Conservation and Utilization of Forest Resources, Sofia Bulgaria, Vol. II, ISBN 954-90896-3-0: 119-127. 